\title{
Sacrospinous colpopexy versus McCall's culdoplasty during vaginal hysterectomy in stage 3 and 4 prolapse for prevention of vault prolapse
}

\author{
S. S. Gulati, Samta Gupta*, Neha Khan, Shelly Agarwal, Naima Afreen, Megha Ranjan
}

School of Medical Science and Research, Sharda University Greater Noida, Uttar Pradesh, India

Received: 11 May 2021

Accepted: 08 June 2021

\author{
*Correspondence: \\ Dr. Samta Gupta, \\ E-mail: samtagup12@gmail.com
}

Copyright: (c) the author(s), publisher and licensee Medip Academy. This is an open-access article distributed under the terms of the Creative Commons Attribution Non-Commercial License, which permits unrestricted non-commercial use, distribution, and reproduction in any medium, provided the original work is properly cited.

\begin{abstract}
Background: Pelvic organ prolapse is a common condition seen in women due to weakening of support of pelvic organs. Different surgical procedures have been adopted for suspension of vaginal vault during vaginal hysterectomy to restore vault to near normal anatomic position as preventive measures for vault prolapse. The aim of study was to compare the efficacy of the McCall's culdoplasty and sacrospinous ligament colpopexy in stage 3 and 4 prolapse (POPQ).

Methods: This prospective study comprised 100 women presenting with stage 3 and 4 prolapse (POP-Q). They were divided into two equal groups of 50 each. The patients were randomized to undergo McCall's culdoplasty (Group A) or sacrospinous ligament fixation (Group B) with vaginal hysterectomy based on note contained in an envelope comparative analysis was done, and patients were evaluated for intra-operative difficulties and immediate (48 hours) post-operative complications using SPSS-version 23 for statistical analysis. The patients were followed up at one month and one year to evaluate symptomatically and objectively.

Results: In group A, patients with 3-degree prolapse 1 woman had hemorrhage and 1 woman had bladder injury intraoperatively. Whereas in group B, 5 women had hemorrhage and 1 woman had rectal injury intraoperatively. All complications were dealt successfully. No other major intra- and post-operative complications occurred.

Conclusions: Vaginal hysterectomy with sacrospinous colpopexy resulted in better outcomes after surgery. Hence, it was concluded that unilateral or bilateral SSLF may be added to vaginal hysterectomy in patients of stage 3 or 4 prolapse.
\end{abstract}

Keywords: Pelvic organ prolapse, Vaginal hysterectomy, McCall Culdoplasty, Sacrospinous ligament fixation

\section{INTRODUCTION}

Pelvic organ prolapse is a condition when one or more of the organs in the pelvis (the uterus, bladder or rectum) descents down from its normal position and bulges into the vagina or out of introitus owing to weakness of tissues supporting these organs. It is a common condition, affecting approximately half of the parous women and it may recur even after hysterectomy, as vault prolapse. Although not a life-threatening condition, women with POP often experience pelvic discomfort, urinary and anal incontinence, sensory and emptying abnormalities of the lower urinary tract, sexual dysfunction, and an overall decrease in their quality of life. Surgery may be considered in situations where prolapse is causing pain, disturbing quality of life or if the patient is having bladder and bowels symptoms.

The cervix and upper vagina are suspended in the pelvis by the cardinal and uterosacral ligaments which fuse with each other at their attachment to cervix and upper vagina. These ligaments attach the cervix and upper vagina to the 
lateral pelvic wall around the greater sciatic foramen and posteriorly to S2 to S4 of sacrum. When these suspensory supports are damaged or weakened the cervix and upper vagina descent down and the tip of cervix comes to lie below its normal position which is at the level of the ischial spine. It is essential that women with advanced prolapse require adequate support of vaginal apex during surgery. Unless the vaginal apex is correctly supported, the surgical repair of the apex, anterior and posterior wall would fail leading to recurrence of prolapse. . $^{1,2}$

The reported incidence of vault prolapse after hysterectomy is 0.2 to $43 \%$ (depending on the preoperative stage, surgical skill and procedure). ${ }^{3}$ Various procedures (namely McCall culdoplasty and sacrospinous ligament fixation, high uterosacral suspension, sacrococcygeal suspension and their modifications) have been described for treatment as well as prevention of vault prolapse with the aim of suspending the vault near to its normal anatomic position.

The sacrospinous ligament courses from the ischial spine to the lateral aspect of the sacrum and fuses medially with the Sacro-tuberous ligament. Sedera was the first to use the sacrospinous ligament as a secure point of attachment for patients with vaginal vault and uterine prolapse as early as 1958. ${ }^{4}$ Randall and Nichols have described the procedure with some modifications. ${ }^{5}$ Advantages of sacrospinous ligament suspension include avoidance of laparotomy and general anesthesia, resulting in fewer complications and less postoperative pain, greater cost effectiveness, a shorter hospital stay, decreased blood loss, and preservation of coital function. ${ }^{6-8}$ However, the procedure is complicated by pelvic hemorrhage, buttock pain, neurovascular injury, urinary retention, urinary tract infection, cuff infection, enterotomy, vaginal hematomas, abscess, bladder, and ureteric injury. The most severe intraoperative complication from SSF, although uncommon, is the pelvic hemorrhage from laceration of the hypogastric venous plexus, pudendal vein, and inferior gluteal artery. Hemorrhage can be managed by tight vaginal packing, arterial ligation. ${ }^{9}$ Buttock pain caused by nerve injury is seen occasionally. If the pain is severe or associated with paresthesia, reoperation and relocation of the suture more medially are often suggested. ${ }^{7}$

\section{METHODS}

This prospective study was aimed to compare the efficacy of two common techniques of vault suspension during vaginal hysterectomy -McCall culdoplasty and sacrospinous ligament fixation.

A total of 100 women were included in the present study. The study was conducted over 3 years from March 2016 to February 2020 and carried out at Sharda hospital, School of Medical Sciences and Research, Greater Noida (Uttar Pradesh).
As a protocol, an informed consent was taken from all the patients prior to the surgery and approval of the institute's ethics committee was also obtained. The statistical analysis was performed using a simple tool of SPSSversion 23. Qualitative data was compared using chi square test and Fischer's exact test while quantitative data was analyzed using student $\mathrm{t}$ test. We assigned a benchmark figure for our results and considered $\mathrm{p}<0.05$ to be significant for our study.

Certain inclusion and exclusion criteria were followed in the study. Women with stage 3, 4 prolapse (POP-Q) from both the groups were included in the study. Women with stage 1, 2 prolapse (POP-Q) and vault prolapse were excluded.

The total numbers of 100 cases considered in the study were divided equally into two groups. The patients were randomized to undergo McCall's culdoplasty or Sacrospinous ligament fixation based on note contained in an envelope which was opened in operation theatre just before surgery. Group A included women who underwent vaginal hysterectomy with McCall culdoplasty and group B included women who underwent vaginal hysterectomy with sacrospinous ligament fixation. Group A and Group $B$ were further analyzed based on the stages 3 and 4 of POP-Q.

\section{Surgical technique}

Group A patients underwent vaginal hysterectomy, with anterior colporrhaphy and posterior colpoperineorrhaphy and Mc Call culdoplasty.

Group B patients underwent vaginal hysterectomy, anterior colporrhaphy. Then, unilateral right sacrospinous ligament fixation was performed (using the technique defined by Nichols) as follows: after hydro dissection, rectovaginal space opened to the vaginal apex, the right pararectal space was entered using blunt dissection; the ischial spine was palpated and taken as the reference to pinpoint the sacrospinous ligament, which extends from the ischial spine medially to the coccyx and the lower portion of the sacrum. ${ }^{5}$ The pararectal fascia was penetrated, and the space was enlarged using blunt dissection; the rectum was retracted to the left using two retractors, thereby exposing the sacrospinous ligament. No 1 suture (vicryl in our study) was placed $2-2.5 \mathrm{~cm}$ medially to the ischial spine, and one end of the suture was passed through the vaginal vault; surplus tissue located in the posterior vaginal wall was excised, dead space was tightly packed with gel foam for hemostasis and the vaginal mucosa was repaired. Following the vaginal vault repair, the vaginal vault was suspended from the right sacrospinous ligament by tying together the sacrospinous sutures located proximal to the apex of the vaginal vault. Lastly, posterior colpoperineorrhaphy was performed, in all the cases. 
Comparative analysis was done, and patients were evaluated for intra-operative difficulties and immediate (48 hours) post-operative complications. The patients were followed up at one month and one year to evaluate symptomatically and objectively. 12 patients were lost to follow up, so they were not included during data analysis.

\section{RESULTS}

On comparison of patient's demographic data there were no statistically significant differences between the two groups in age, parity, and reasons for presentation to hospital. The mean age of the patients was 58.73 years ( \pm 3.5 years) in case of group A and the mean parity was $4.62( \pm 1.13)$. Similarly, the mean age of the patients in group B was 57.81 years $( \pm 4.8$ years $)$ and mean parity was $4.20( \pm 1.05)$ (Table 1$)$.

Table 1: Demographic profile.

\begin{tabular}{|llll|}
\hline Variables & $\begin{array}{l}\text { Group A } \\
\text { (McCall) }\end{array}$ & $\begin{array}{l}\text { Group B } \\
\text { (SSL) }\end{array}$ & P value \\
\hline $\begin{array}{l}\text { Age } \\
\text { (years) }\end{array}$ & $58.73 \pm 3.5$ & $57.81 \pm 4.8$ & 0.312 \\
\hline Parity & $4.62 \pm 1.13$ & $4.20 \pm 1.05$ & 0.081 \\
\hline
\end{tabular}

Nine women amongst group A and seven women amongst group B (Table 2) had systemic medical problems, but we did not expect any contraindication with the surgery in any of them after full evaluation.

Table 2: Associated medical conditions.

\begin{tabular}{|c|c|c|c|}
\hline Conditions & $\begin{array}{l}\text { Group A, } \\
(\mathbf{n}=45) \\
(\%)\end{array}$ & $\begin{array}{l}\text { Group B, } \\
(\mathrm{n}=\mathbf{4 3}) \\
(\%)\end{array}$ & $P$ value \\
\hline Obesity & $3(6.67)$ & $1(2.32)$ & \multirow{4}{*}{0.545} \\
\hline Constipation & $1(2.22)$ & $2(4.65)$ & \\
\hline Smoker & $5(11.11)$ & $4(9.301)$ & \\
\hline $\begin{array}{l}\text { Chronic } \\
\text { lung } \\
\text { disease }\end{array}$ & 0 & 0 & \\
\hline
\end{tabular}

In group A who underwent vaginal hysterectomy with McCall culdoplasty, 9 women had stage 3, pre-operative degree of prolapse and 36 women had stage 4 preoperative degree of prolapse. Out of these numbers, 1 woman had hemorrhage intraoperatively and 1 woman had bladder injury during the surgery. Whereas in group B who underwent vaginal hysterectomy with sacrospinous ligament fixation, 7 women had stage 3, pre-operative degree of prolapse and 36 women had stage 4 preoperative degree of prolapse. Out of them, 5 women had hemorrhage intraoperatively which was managed conservatively by hot packs and packing, 3 women had rectal injury during the surgery. Rectal injury was treated with immediate closure, fluid, and soft diet for 3-5 days. Location of rectal injury was lower half of rectum in all cases (Table 3 and 4).
Table 3: Pre-operative degree of prolapse.

\begin{tabular}{|llll|} 
Variables & $\begin{array}{l}\text { Group A, } \\
(\mathbf{n = 4 5})(\boldsymbol{\%})\end{array}$ & $\begin{array}{l}\text { Group B, } \\
(\mathbf{n = 4 3 )}(\boldsymbol{\%})\end{array}$ & P value \\
\cline { 1 - 3 } Stage 3 & $9(20)$ & $7(16.28)$ & \multirow{2}{*}{0.651} \\
\cline { 1 - 3 } Stage 4 & $36(80)$ & $36(83.72)$ & \\
\hline
\end{tabular}

The mean duration of surgery (in min) in group A was $77.77( \pm 21.46)$. Group B took more time, mean time taken was $141.86( \pm 29.9)$ min (Table 4$)$.

Table 4: Intra-operative complications.

\begin{tabular}{|c|c|c|c|}
\hline Variables & $\begin{array}{l}\text { Group A } \\
\text { (McCall) } \\
(\%)\end{array}$ & $\begin{array}{l}\text { Group B } \\
\text { (SSLF) } \\
(\%)\end{array}$ & P value \\
\hline Haemorrhage & $1(2.22)$ & $5(11.63)$ & \multirow{3}{*}{0.169} \\
\hline Rectal injury & 0 & $3(6.98)$ & \\
\hline Bladder injury & $1(2.22)$ & 0 & \\
\hline $\begin{array}{l}\text { Duration of } \\
\text { surgery } \\
\text { (min) }\end{array}$ & $\begin{array}{l}77.77 \\
( \pm 21.46)\end{array}$ & $\begin{array}{l}141.86 \\
( \pm 29.9)\end{array}$ & 0.001 \\
\hline
\end{tabular}

In post-operative period within a week, 2 cases had voiding dysfunction and 1 woman had hematoma formation in group A category (vaginal hysterectomy with McCall culdoplasty). Whereas, in group 2 category (vaginal hysterectomy with sacrospinous ligament fixation), 1 woman had voiding dysfunction, 7 had gluteal pain which was statistically significant, and 2 had hematoma formation (Table 5).

Table 5: Post-operative complications (within 1 week).

\begin{tabular}{|llll|}
\hline Variables & $\begin{array}{l}\text { Group A } \\
\text { (McCall) } \\
(\%)\end{array}$ & $\begin{array}{l}\text { Group B } \\
\text { (SSLF) } \\
(\%)\end{array}$ & $\begin{array}{l}\text { P } \\
\text { value }\end{array}$ \\
\hline $\begin{array}{l}\text { Voiding } \\
\text { dysfunction }\end{array}$ & $2(4.44)$ & $1(2.33)$ & 0.59 \\
\hline $\begin{array}{l}\text { Gluteal } \\
\text { pain }\end{array}$ & 0 & $7(16.28)$ & 0.009 \\
\hline $\begin{array}{l}\text { Haematoma } \\
\text { formation }\end{array}$ & $1(2.22)$ & $2(4.65)$ & 0.544 \\
\hline $\begin{array}{l}\text { Cuff } \\
\text { cellulitis }\end{array}$ & 0 & 0 & \\
\hline $\begin{array}{l}\text { Hospital } \\
\text { stays (days) }\end{array}$ & $3.93 \pm 0.65$ & $4.44 \pm 1.11$ & 0.01 \\
\hline
\end{tabular}

The average length of stay for group A cases was $3.93 \pm 0.65$ days and the length of stay for group B was more $4.44 \pm 1.11$ days.

Follow up one-month post-operative evaluation of staging of prolapse revealed, 33 women had stage 1 and 22 cases still had stage 2 in group A category. Whereas 33 cases had no prolapse stage 0 and only 10 cases had stage 1 in group B category which were the statistically significant (Table $6)$. 
Table 6: Post-operative staging of prolapse (after one month).

\begin{tabular}{|c|c|c|c|c|}
\hline Variables & & $\begin{array}{l}\text { Group A } \\
\text { (McCall) } \\
(\%)\end{array}$ & $\begin{array}{l}\text { Group B } \\
\text { (SSLF) } \\
(\%)\end{array}$ & P value \\
\hline \multirow{3}{*}{$\begin{array}{l}\text { Post- } \\
\text { operative } \\
\text { staging } \\
\text { of } \\
\text { prolapse } \\
\text { (After } 1 \\
\text { month) }\end{array}$} & $\begin{array}{l}\text { Stage } \\
0\end{array}$ & 0 & $\begin{array}{l}33 \\
(76.74)\end{array}$ & 0.001 \\
\hline & $\begin{array}{l}\text { Stage } \\
1\end{array}$ & $\begin{array}{l}33 \\
(73.33)\end{array}$ & $\begin{array}{l}10 \\
(23.26)\end{array}$ & 0.005 \\
\hline & $\begin{array}{l}\text { Stage- } \\
2\end{array}$ & $\begin{array}{l}12 \\
(26.67)\end{array}$ & 0 & 0.003 \\
\hline
\end{tabular}

Post-operative evaluation at one year revealed, 3 cases had recurrent cystocele, 1 case had recurrent rectocele and 2 cases had vault prolapse in group A category. In group B category, one-year post-operative evaluation showed only 1 case $(2.32 \%)$ had recurrent cystocele. There was no vault prolapse in SSLF group (Table 7).

Table 7: Post-operative evaluation (At one year).

\begin{tabular}{|llll|}
\hline Variables & $\begin{array}{l}\text { Group A } \\
\text { (McCall) } \\
(\%)\end{array}$ & $\begin{array}{l}\text { Group B } \\
(\text { SSLF) } \\
(\%)\end{array}$ & P value \\
\hline $\begin{array}{l}\text { Recurrent } \\
\text { cystocele }\end{array}$ & $3(6.67)$ & $1(2.32)$ & 0.35 \\
\hline $\begin{array}{l}\text { Recurrent } \\
\text { rectocele }\end{array}$ & $1(2.22)$ & 0 & 0.331 \\
\hline $\begin{array}{l}\text { Recurrent } \\
\text { vault } \\
\text { prolapses }\end{array}$ & $2(4.44)$ & 0 & 0.171 \\
\hline
\end{tabular}

\section{DISCUSSION}

As the recurrence rates of POP is high different surgical interventions like mesh, sacrospinous fixation (unilateral and bilateral), high uterosacral fixation, abdominal colpopexy etc. have been tried to augment prolapse repairs Several studies in the literature have investigated the outcomes of SLF. The purpose of our study was to compare whether prophylactic unilateral SLF added to vaginal hysterectomy in management of patients with stage 3 or 4 pelvic organ prolapse has better outcome in comparison to McCall culdoplasty with vaginal hysterectomy. Comparative analysis was done in terms of intra-operative and post-operative complications \& anatomical outcomes after 1 month and 1 year.

Correlation of our results was done with different published studies and a systemic review done by Tseng et al of twenty-seven published articles on outcomes of SSF as a point of attachment for POP. ${ }^{10}$

Comparing the two surgical options, it was observed that most severe intra-operative complication noted was pelvic hemorrhage which was more in SSLF group-(11.63\%) as compared to McCall culdoplasty group. This complication may occur due to laceration of hypogastric venous plexus, pudendal vein which are in close proximity to sacrospinous ligament. Intraoperative hemorrhage was managed with hot packs, pressure and spongeston. Elif et al reported a similar incidence of $18.8 \% .^{11}$ However, incidence reported by Gupta et al and Hefani et al was $1.9 \%$ and $1.8 \%$ respectively. ${ }^{12,13}$

Statistically significant complication that was noted post operatively within one week of surgery was gluteal pain, which was more common in the SSLF group-7 (16.28\%). Our incidence was comparable to studies by Guner et al and Elif et al who reported $18 \%$ and $21.9 \%$ incidence of gluteal pain and nerve injury. ${ }^{11,14}$ If the pain is severe or associated with paresthesia, reoperation and relocation of the suture more medially are often suggested but in our study the pain was transient and subsided within 7 to 30 days of surgery by analgesics and anti-inflammatory agents. $^{7}$

Colombo and Milani compared SLF with McCall culdoplasty and found that the latter yielded better results in terms of length of operation, blood loss as approaching the sacrospinous ligament requires additional tissue dissection which is not the case in McCall culdoplasty. ${ }^{15}$ Mean operative time taken for SLF was higher in comparison to McCall culdoplasty in our study as more time is required to reach the sacrospinous ligament even in hands of experienced surgeon.

When comparing postoperative staging in both the groups post-surgery one-month, better outcomes were observed in SSLF group with $76.74 \%$ in stage 0 (POP-Q). On observing other studies on same parameters, similar results were observed by Gayathri et al where $66.67 \%$ cases achieved stage 0 post operatively. ${ }^{16}$ In our study one-year post-operative evaluation only 1 case $(2.32 \%)$ had recurrent cystocele and there was no vault prolapse in SLF group. Overall cure rate was $97.6 \%$. In systemic review by Tseng et al twenty-four studies reported an overall cure rate of $84.6 \%$ (range 69 to $100 \%$ ) and 21 studies reported the following recurrence rates: apex 5.3\%, range 0 to $14 \%$; anterior $18.3 \%$, range 0 to $42 \%$; and posterior $2.4 \%$, range 0 to $1 \% .{ }^{10}$ Sze et al reviewed the outcomes of 1062 patients undergoing SSF. ${ }^{7}$ Long-term outcomes seemed to be satisfactory and apical recurrences were not often observed. Retroversion of the vagina leading to an unprotected anterior vaginal wall has been suggested to predispose to cystocele formation. However, Smilen et al reported that concomitant SSF with anterior repair did not affect the incidence of recurrent cystoceles. ${ }^{17}$ They proposed maintenance of anterior wall length during SSF to be an important technical point in avoiding anterior wall recurrence. Subsequently, Shull et al emphasized recognition and repair of all anatomic defects, especially in the anterior vaginal wall, as important technical points in preventing anterior wall recurrence. ${ }^{18}$

A similar study by RCOG indicated that McCall culdoplasty at the time of vaginal hysterectomy is effective in preventing subsequent post hysterectomy vault 
prolapse. ${ }^{19}$ But sacrospinous fixation at the time of vaginal hysterectomy should be considered when the vault descends to the introitus during closure.

\section{Limitations}

Since all the operative procedures were not carried out by same surgeon it could have led to bias in the homogeneity of the surgical results. It has a short follow up and sample size is not large.

\section{CONCLUSION}

Though, vaginal hysterectomy with sacrospinous ligament fixation was found to be associated with increased duration of surgery and excess blood loss, hospital stay and early complications, however it resulted in better outcomes after the surgery. However further studies are required with large sample size.

Hence, unilateral, or bilateral SSLF may be added to vaginal hysterectomy in patients of stage 3 or 4 prolapse who are expected to have long survival time for better results.

\section{ACKNOWLEDGMENTS}

Author would like to thank the resident doctors and staffs of Sharda hospital for their support.

Funding: No funding sources Conflict of interest: None declared

Ethical approval: The study was approved by the Institutional Ethics Committee

\section{REFERENCES}

1. Rooney K, Kenton K, Mueller ER, FitzGerald MP, Brubaker L. Advanced anterior vaginal wall prolapse is highly correlated with apical prolapse. Am J Obstet Gynecol. 2006;195(6):1837-40.

2. Barber MD, Maher C. Apical prolapse. Int Urogyn Ecol J. 2013;24(11):1815-33.

3. Abrams P, Cardozo L, Fall M, Griffiths D, Rosier P, Ulmsten U et al. Standardization. Subcommittee of the International Continence Society. The standardization of terminology of lower urinary tract function: report from the standardization subcommittee of the international continence society. Neurourol Urodyn. 2002;21:167-8.

4. Sedera L. Surgery in prolapse of a blind-end vagina. Geburtshilfe Frauenheilkd. 1958;18:824-8.

5. Randall CL, Nichols DH. Surgical treatment of vaginal inversion. Obstet Gynecol. 1971;38:327-32.

6. Holley RL, Varner RE, Gleason BP, Apffel LA, Scott S. Recurrent pelvic support defects after sacrospinous ligament fixation for vaginal vault prolapse. J Am Coll Surg. 1995;180: 444-8.

7. Sze EH, Karram MM. Transvaginal repair of vault prolapse: a review. Obstet Gynecol. 1997;89:466-75.

8. Toozs-Hobson P, Boos K, Cardozo L. Management of vaginal vault prolapse. $\mathrm{Br} \mathrm{J}$ Obstet Gynaecol. 1998;105:13-7.

9. Cruikshank SH, Muniz M. Outcomes study: a comparison of cure rates in 695 patients undergoing sacrospinous ligament fixation alone and with other sitespecific procedure 16-year study. Am J Obstet Gynecol. 2003;188:1509-15.

10. Ling-Hong Tseng, Ilene Chen, Shuenn-Dyh Chang, Chyi-Long Lee. Modern role of sacrospinous ligament fixation for pelvic organ prolapse surgery A systemic review. Taiwanese J Obstetr Gynecol. 2013;52:311-7.

11. Ağaçayak E, Tunç SY, İçen MS, Başaranoğlu S, Fındık FM, Sak $S$ et al. Should we add unilateral sacrospinous ligament fixation to vaginal hysterectomy in management of stage 3 and stage 4 pelvic organ prolapse? Turk J Obstet Gynecol. 2015;12:144-50.

12. Gupta P. Transvaginal sacrospinous ligament fixation technique, as part of the vaginal repair procedure for massive uterovaginal (Pelvic Organ Prolapse stage III and stage IV and vault prolapse. Iran $\mathrm{J}$ Med sci. 2015;40:1

13. Hefni M, El-Toukhy T, Bhaumik J, Katsimanis E. Sacrospinous cervicocolpopexy with uterine conservation for uterovaginal prolapse in elderly women: an evolving concept. Am J Obstet Gynecol. 2003; 188:645-50.

14. Guner H, Noyan V, Tiras MB, Yildiz A, Yildirim M. Transvaginal sacrospinous colpopexy for marked uterovaginal and vault prolapse. Int J Gynecol Obstet. 2001;74:165-70.

15. Colombo M, Milani R. Sacrospinous ligament fixation and modified McCall culdoplasty during vaginal hysterectomy for advanced uterovaginal prolapse. Am J Obstet Gynecol. 1998;179:13-20.

16. Gayathri KB, Gurumurthy R, Bhargav PRK, Rapoor S, Devi VN. Sacrospinous fixation for prevention and treatment of vault prolapse: institutional experience from South India. Int J Reprod Contracept Obstet Gynecol. 2014;3(2):380-4.

17. Smilen SW, Saini J, Wallach SJ, Porges RF. The risk of cystocele after sacrospinous ligament fixation. Am J Obstet Gynecol. 1998;179:1465-71.

18. Shull BL, Capen CV, Riggs MW, Kuehl TJ. Preoperative and postoperative analysis of site-specific pelvic support defects in 81 women treated with sacrospinous ligament suspension and pelvic reconstruction. Am J Obstet Gynecol. 1992;166:1764-8.

19. RCOG/BSUG Joint Guideline. Green-top Guideline No. 46 Post-Hysterectomy Vaginal Vault Prolapse. 2015.

Cite this article as: Gulati SS, Gupta S, Khan N, Agarwal S, Afreen N, Ranjan M. Sacrospinous colpopexy versus McCall's culdoplasty during vaginal hysterectomy in stage 3 and 4 prolapse for prevention of vault prolapse. Int J Reprod Contracept Obstet Gynecol 2021;10:2825-9. 